\title{
Winter-forage crop grazing in the Gore-Mataura area of Southland: using time-series mapping to estimate location and frequency of cropping
}

\author{
John J. DREWRY ${ }^{1 *}$, Heather NORTH ${ }^{2}$, Stella E. BELLISS ${ }^{2}$, Alexander AMIES ${ }^{2}$. \\ ${ }^{1}$ Manaaki Whenua - Landcare Research, Private Bag 11052, Palmerston North 4442, New Zealand \\ ${ }^{2}$ Manaaki Whenua - Landcare Research, PO Box 69040, Lincoln 7640, New Zealand \\ *Corresponding author: drewryj@landcareresearch.co.nz
}

\begin{abstract}
Winter grazing of forage crops is a key land-use in southern New Zealand, providing important feed for livestock but has been identified as risky if not managed well, potentially resulting in soil degradation and nutrient losses. We hypothesised that analysing an existing time series of winter-forage maps, derived from satellite imagery could be used to identify how often paddocks are re-used for winter forage. A pilot study was undertaken to explore the practicality and utility of this new method by examining maps derived from satellite images of the Gore-Mataura area, Southland taken in 2013, 2014, 2017, and 2018. Within the study site $(67,618 \mathrm{ha}), 8925$ ha was classed as winter forage in one or more of the source maps. Eighty-five percent of this area was used in only one of the four years, and just $1 \%$ in three or four years. High-certainty class pairs for 2013/14 and 2017/18 show two consecutive years of winter forage in the same paddock, $31 \%$ or $21 \%$ of the time, respectively. These winter-forage crops were generally grown on Brown soils (63\%), followed by Pallic and Gley soils. Although, this study was limited by differences in the mapping methodologies of the source maps, it nonetheless demonstrated that potentially valuable data can be derived. It showed a low level of repeat use of paddocks for winter forage grazing over all the years studied, and that Brown soils are more commonly used for winter forage than previous studies suggested.
\end{abstract}

Keywords: Forage crop, winter feed, brassica, nutrient loss, water quality, catchment.

\section{Introduction}

Winter-forage cropping and grazing by break feeding has been identified as a key land-use pressure and a high-risk land-management practice in New Zealand because it can result in soil structural degradation, nutrient leaching losses and sediment losses (McDowell et al. 2003a; Drewry \& Paton 2005; Houlbrooke et al. 2009; Monaghan et al. 2017; Thomas et al. 2019). Crops including kale (Brassica oleracea), swedes (B. napus), turnips (B. rapa), rape (Brassica napus spp. biennis), fodder beet (Beta vulgaris), and some cereals (e.g. oats Avena sativa) are commonly used as wintergrazed forage crops in southern New Zealand (Drewry \& Paton 2005; Smith et al. 2012; Pearson et al. 2016; Carey et al. 2017).

Risk of sediment loss increases when vegetation cover is removed and on slopes $\geq 7^{\circ}$. In recent national research, Manaaki Whenua - Landcare Research (MWLR) identified Southland as the region with the most winter-forage cropping in hill country, as a percentage of all hill-country agricultural land in 2018 (Belliss et al. 2019). As part of the Essential Freshwater policy development processes and this national mapping, hill country was defined as paddocks with average slope $\geq 7^{\circ}$, as the interest was in the potential for sediment runoff (Belliss et al. 2019). Winterforage cropping on free-draining soils on flat land in Southland is also considered a risk to waterways due to high nitrate loads from leaching (Smith et al. 2012). Risk of nitrate leaching losses increase when soils are shallow (e.g. $<45 \mathrm{~cm}$ to gravel), as these soils generally have low available water-holding capacity (Smith et al. 2012; Carrick et al. 2013). There is a need to better understand potential risks associated with soil types, soil characteristics such as drainage, and other factors for nutrient and sediment movement. In future, combining this information with paddock-scale landuse data in Southland should improve understanding and modelling of potential environmental impacts to water quality.

A pilot study of paddock-scale mapping of winterforage grazing undertaken in 2013 (North et al. unpublished report) and subsequent mapping across the whole of Southland in 2014 (North \& Belliss 2015) were used to evaluate potential impacts and policy implications of the Southland Water and Land Plan proposed in 2016. Pearson et al. (2016) recommended that further work was needed in the future to assess the extent of winter-forage cropping in Southland over an extended time period to help reduce uncertainty around the implications of possible policy changes.

We have found few studies exploring the effect of repeated use of individual paddocks for winter forage. Judson et al. (2010) noted that paddocks used repeatedly may be subject to cumulative damage, 
whereas if cropped just once as part of a pasture renewal programme, the soil damage could be seen as short term. Smith et al. (2012) showed increased annual nitrate losses from successive winter-grazed crops. In contrast, Monaghan et al. (2017) did not find any significant downward trend in total porosity or pore size distribution across three consecutive years of forage grazing. Here, we use a study site in eastern Southland agricultural hill country and flat land to evaluate both the area of forage grazing in any one year and the incidence re-cropping and therefore re-grazing of individual paddocks. We also briefly evaluate the soil order and drainage class characteristics within the winter cropped areas to help inform future research.

\section{Materials and Methods Overall approach}

We investigated a time series of existing winter-forage maps for eastern Southland for the years 2013, 2014, 2017, and 2018 for a case-study site of $32 \mathrm{~km}$ by $32 \mathrm{~km}$, around the Gore-Mataura area. For over a decade, MWLR has been developing and improving methods to map agricultural land-use and crop type using satellite imagery, and the winter forage maps used in this work were originally generated by MWLR in separate projects for several organisations. Thus, different methods and slightly different sets of output classes were used on each occasion. These are outlined below. For time series analysis, it would clearly be preferable to have complete consistency among all source maps. However, the dataset used here is the only example of which we are aware of existing paddockscale winter-forage maps forming a significant timeseries over any one area of New Zealand. Thus, it presents an opportunity to derive preliminary multiyear data, while assessing any difficulties with the dataset and analysis method for future reference.

\section{Winter-forage source maps}

The features of the four winter-forage maps used in this analysis are summarised in Table 1. The specific methods and results for each source map reside in reports for the relevant client so a summary of the overall approach used in producing such maps is provided here. In general, a March to September time series of satellite imagery is used for each map, from full-leaf cover of the forage crop in autumn to increasing bare ground during winter and early spring. Spectral classification of the satellite imagery broadly identifies vegetation types and bare ground, and a series of rules is applied to identify expected temporal patterns of vegetation removal.

Each project used imagery available at the time, first from SPOT satellites (4 spectral bands, 10-m spatial resolution) and the Landsat satellite series (7 bands, 30-m spatial resolution) and, more recently, from Sentinel-2 (13 spectral bands, 10-m spatial resolution). For each project, images were selected to obtain geographic and temporal coverage, with heavily cloudaffected images excluded. Remaining cloud, shadow, and snow were masked out, using methods progressing from manual processing in earlier years (e.g. delineation of cloud by visual assessment) to a more automated process in later years. Non-agricultural land was also masked out, with methods also progressing from spectral classification and manual delineation to GIS analysis of NZ Land Cover Database and Department of Conservation data layers. In most cases, the method of North et al. (2019) was used to delineate paddock polygons, so that the winter-forage map could be derived and presented as a GIS layer, rather than a raster (per-pixel) result.

\section{Map processing}

For this paper, all four results were clipped to the original 2013 study area. The bounding box of this area is $32 \times 32 \mathrm{~km}$, but it is an irregular-shaped quadrilateral corresponding to the joint coverage of the three SPOT quarter-scenes used in 2013 that covers 67,618 ha. Each of the four maps used a slightly different set of landcover/land-use classes due to factors including client requirements, fieldwork and satellite imagery available at the time, and progress in mapping methods. One key difference is that the SPOT and Landsat imagery used in the earlier years provides poor discrimination between brassica and fodder beet, and the latter is expected to be lumped with the former. In contrast, Sentinel-2 imagery provides much improved discrimination between these two classes, as well as between pasture and winter-forage oats. From each of the four maps we have extracted the classes most likely to be winterforage grazing or pasture grazed to bare soil using a simple Arc model that was written to select polygons based on their land-use class attribute (attribute names vary across the four maps). Geoprocessing was carried out using ESRI ArcMap version 10.2.1. The selected classes are shown in Table 2.

\section{Frequency classes}

We estimated the frequency with which winter forage occurred throughout the four years based on the winterforage paddock maps described above. Although the data series spanned six years from 2013 to 2018, maps only existed for four of those (years 2015 and 2016 have not been mapped), so our frequency values do not represent the true proportion of years grazed out of six, but indicate the minimum occurrence of repeated paddock use. The area for each of the frequency classes was calculated as follows: 
Table 1 Information regarding the four winter-forage source maps used in this study

\begin{tabular}{|c|c|c|c|c|}
\hline \multirow[b]{2}{*}{ Details } & \multicolumn{4}{|c|}{ Year } \\
\hline & 2013 & 2014 & 2017 & 2018 \\
\hline Reference & $\begin{array}{l}\text { Unpublished contract } \\
\text { report }^{1}\end{array}$ & $\begin{array}{l}\text { North and Belliss } \\
(2015)\end{array}$ & $\begin{array}{l}\text { Unpublished } \\
\text { contract report }^{2}\end{array}$ & Belliss et al. (2019) \\
\hline Area mapped & $\begin{array}{l}\text { Gore-Mataura } \\
32 \mathrm{~km} \times 32 \mathrm{~km} \text { study area }\end{array}$ & Whole Southland region & Whole Southland region & $\begin{array}{l}\text { Land } \geq 7^{\circ} \text { slope across } \\
\text { whole of New Zealand }\end{array}$ \\
\hline Satellite imagery & SPOT-5 & Landsat & Landsat and Sentinel-2 & Sentinel-2 \\
\hline $\begin{array}{l}\text { No. images obtained from } \\
\text { March to September }\end{array}$ & 3 & 10 & $\begin{array}{l}10 \text { Sentinel-2 } \\
9 \text { Landsat-8 }\end{array}$ & 4 \\
\hline Results obtained & Both raster and vector & $\begin{array}{l}\text { Raster (per-pixel) } \\
\text { result only }\end{array}$ & $\begin{array}{l}\text { Vector (per-paddock) } \\
\text { result }\end{array}$ & $\begin{array}{l}\text { Vector (per-paddock) } \\
\text { result for steeper land }\end{array}$ \\
\hline Result used & $\begin{array}{l}\text { Multi-temporal } \\
\text { vector result }\end{array}$ & $\begin{array}{l}\text { Raster result converted } \\
\text { to vector format }\end{array}$ & $\begin{array}{l}\text { Vector (per-paddock) } \\
\text { result }\end{array}$ & $\begin{array}{l}\text { Same method applied to } \\
\text { cover the flatter land } \\
\text { in the study site }\end{array}$ \\
\hline
\end{tabular}

${ }^{1}$ North H, Belliss S, Pairman D. 2014. Mapping winter livestock forage in Southland. [Landcare Research Contract Report LC1785 for Environment Southland]. Lincoln: Landcare Research, $36 \mathrm{p}$.

${ }^{2}$ North H, Belliss S, Pairman D. 2018. Winter livestock forage map: Southland region 2017. [Landcare Research Contract Report LC3179 for Environment Southland]. Lincoln: Landcare Research, $26 \mathrm{p}$.

Table 2 Comparison of winter-forage class names and certainties

\begin{tabular}{lll}
\hline & & \multicolumn{2}{c}{ Class(es) } \\
\cline { 2 - 3 } Year & Higher certainty & Lower certainty \\
\hline 2013 & Brassica grazed to bare soil by July/September & $\begin{array}{l}\text { Brassica throughout period, late-planted brassica, pasture } \\
\text { grazed by July, lower probability brassica and pasture }\end{array}$ \\
2014 & $\begin{array}{l}\text { Winter forage (likely swede or brassica) } \\
\text { Winter forage (possibly cereal) }\end{array}$ & Low-certainty swede or brassica, low-certainty cereal forage \\
2017 & $\begin{array}{l}\text { Winter forage kale or other brassica/swede, } \\
\text { fodder beet, cereal }\end{array}$ & Unknown winter grazing, other winter grazing \\
& $\begin{array}{l}\text { All polygons identified as winter forage or pasture } \\
\text { grazed to bare soil, followed by manual checking step }\end{array}$ & \\
\hline
\end{tabular}

1. Winter-forage frequency for the 2013/2014 pair: (a) counting only the high-certainty mapped cases; (b) counting both the high-certainty and low-certainty cases. Values can be 2 (both years), 1 (one year or the other) or 0 (neither year).

2. Winter-forage frequency for the 2017/2018 pair: same as described for the 2013/2014 pair.

3. Winter-forage frequency across all four map dates: (a) counting only the high-certainty mapped cases; (b) counting both the high-certainty and lowcertainty cases. Values can be 0 (never winter forage), 1 (forage in one year only), 2 (forage in any two years), 3 (forage in any three years), or 4 (forage in all four years).

\section{Soil order and drainage class}

Soil order from the New Zealand Soil Classification (Hewitt 2010), and soil drainage class data were obtained from the MWLR digital soil mapping system, S-map (https://doi.org/10.7931/L1WC7) (Lilburne et al. 2012). Further information on soil drainage class is available elsewhere (Milne et al. 1995). The soil sibling - a component of soil classification hierarchy - (Lilburne et al. 2012), drainage code and soil order were extracted from S-map and, where S-map was not available, were obtained from the MWLR digital Fundamental Soil Layer (FSL; https://lris.scinfo.org. $\mathrm{nz} / \mathrm{search} / \mathrm{q}=\mathrm{qSL}$ ). Summary statistics for soil order and drainage class were generated for all winter-forage crop areas that were classed as high certainty. 


\section{Results}

\section{Time-series analysis}

Results of the time-series analysis and data extraction for each of the four years are shown in Table 3, with the area in winter forage for different frequency classes in Table 4.

The data in Table 3 indicated an apparent decreasing trend in total winter-forage area if the high- and lowcertainty classes are combined. However, the area classified with low certainty was reduced from 3551 ha to zero ha over the study period due to improved image processing. Therefore, only the area classified with high certainty was included for the remainder of this work even though this approach may have led to a slight underestimate of area in some years.

The total area classified with high certainty for winter-forage cropping across the four years mapped was 8925 ha (the final row of Table 4). Of this, $85 \%$ (7548 ha) was used in only one of the four years, a further $14 \%$ (1285 ha) in any two of the years, and only $1 \%$ (92 ha) used in three or four of the years. Note that the years in forage cropping are not necessarily consecutive.

The winter-forage frequency based on highcertainty classes only in the 2017/2018 images is shown in Figure 1. This pair and the 2013/14 pair (Additional Online File) also provide an indication, in a subset of the data, of how often winter forage occurs in the same paddocks in consecutive years, but only for each pair due to the 2015/2016 gap. For example, of the 1991 ha of high-certainty winter forage in 2013, there were 618 ha that were also re-cropped in that second year of the pair (31\%; Tables 3 and 4). Of the 2895 ha of high- certainty winter forage in 2017,602 ha $(21 \%)$ were recropped in 2018 (Tables 3 and 4).

\section{Soil order and drainage class}

Within the 8925 ha of land area used for winter-forage grazing (high certainty) across all the years, Brown soils were the most common, accounting for $63 \%$, followed by Pallic soils (21\%) and Gley soils (13\%; Table 5). Of this total area, $62 \%$ is classed as imperfectly or poorly drained (Table 6).

\section{Discussion}

The total area of agricultural land across the Southland Region reported in North and Belliss (2015) is $1,055,495$ ha. The current study evaluated 67,618 ha of which about 20,000 ha was non-agricultural land. The average high-certainty forage area across the four years studied is 2605 ha, i.e. approximately $5 \%$ of the agricultural land. Based on North and Belliss (2015), Pearson et al. (2016) reported about 68,000 ha of winter forage crops in 2014 for all of Southland, i.e. approximately $6 \%$ of the agricultural land. Therefore, we consider our study site is fairly representative of the whole of Southland in terms of winter-forage use. Belliss et al. (2019) mapped only the steeper land in 2018 (paddocks with average slope $\geq 7^{\circ}$ ), reporting 7938 ha of winter forage and heavily grazed pasture in Southland, constituting $2.2 \%$ of the steeper agricultural land mapped.

It is important to note that a large area was classified as low-certainty forage (including heavily grazed pasture) in the 2013 pilot study. Some of this area is likely to be correctly identified but other paddocks will

Table 3 Total area used for winter forage for each of the four years in the study area

\begin{tabular}{lccc}
\hline Year & $\begin{array}{c}\text { Winter-forage high } \\
\text { certainty (ha) }\end{array}$ & $\begin{array}{c}\text { Winter-forage low } \\
\text { certainty (ha) }\end{array}$ & $\begin{array}{c}\text { Winter-forage high + low } \\
\text { certainty. Total (ha) }\end{array}$ \\
\hline 2013 & 1991 & 3551 & 5542 \\
2014 & 3457 & 288 & 3745 \\
2017 & 2895 & 227 & 3122 \\
2018 & 2080 & 0 & 2080 \\
\hline
\end{tabular}

Table 4 Area in winter forage for different frequency classes (ha) in study area, for two mapping classes ( $\mathrm{H}=$ high certainty only; $\mathrm{H}+\mathrm{L}=$ both high and low certainty). Frequencies are not necessarily consecutive years.

\begin{tabular}{lcccccccc}
\hline Frequency & \multicolumn{2}{c}{ Any 1 year } & \multicolumn{2}{c}{ Any 2 years } & \multicolumn{2}{c}{ Any 3 years } & All 4 years \\
\hline Certainty & H & H+L & H & H+L & H & H+L & H & H+L \\
\hline $2013 / 14$ pair & 4212 & 7254 & 618 & 1016 & & & & \\
2017/18 pair & 3771 & 3928 & 602 & 637 & & & \\
Four years & 7548 & 10074 & 1285 & 1919 & 66 & 149 & 32 \\
\hline
\end{tabular}




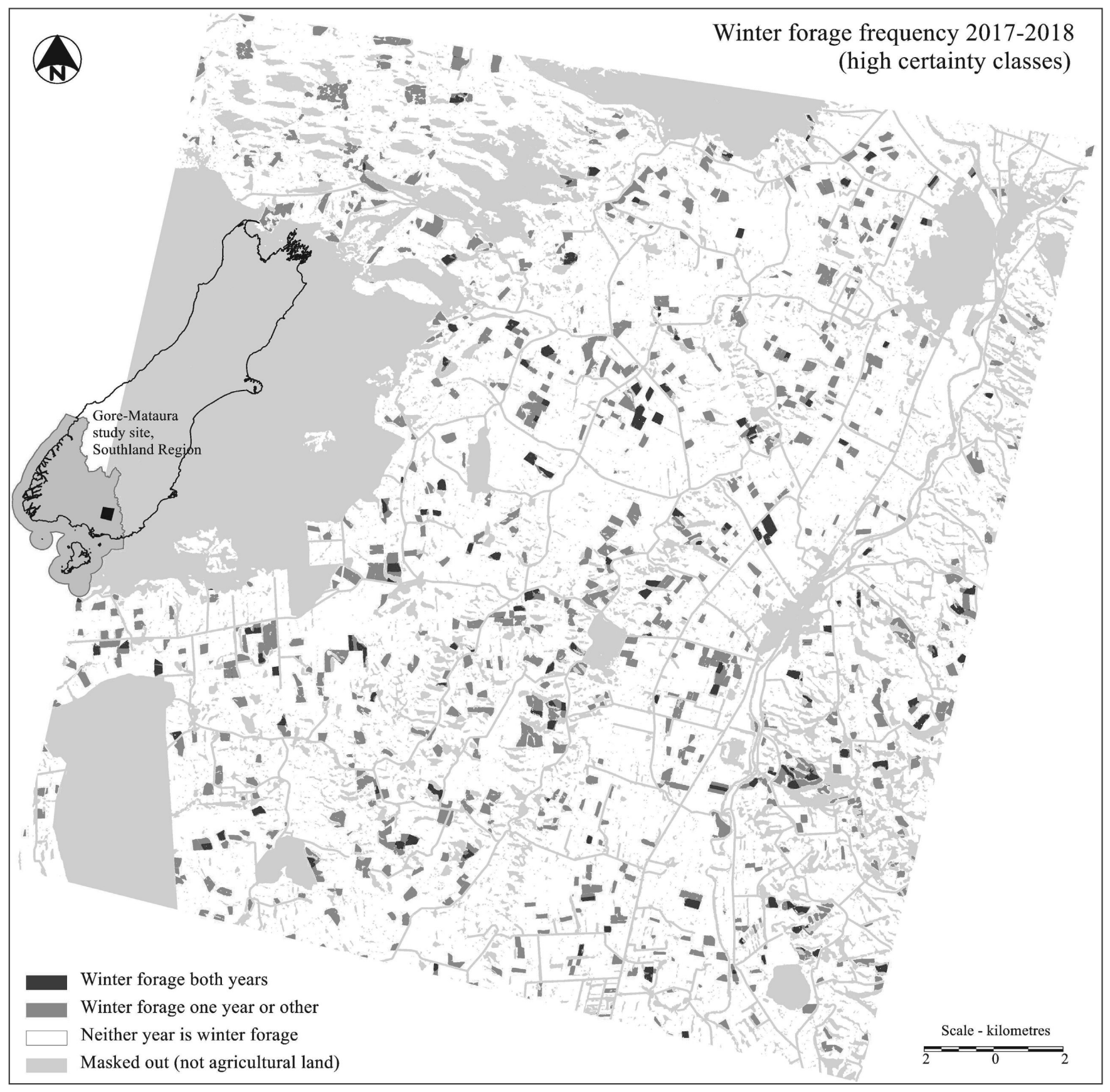

Figure 1 Winter-forage frequency for high-certainty classes in both 2017 and 2018, in the Gore-Mataura area, Southland.

Table 5 Percentage area and area of soil order classification for winter-grazed forage crop paddocks for different frequency classes, for high certainty classifications only

\begin{tabular}{|c|c|c|c|c|c|c|c|c|c|}
\hline $\begin{array}{l}\text { Frequency } \\
\text { (years cropped) }\end{array}$ & $\begin{array}{c}\text { Anthropic } \\
(\%)\end{array}$ & $\begin{array}{c}\text { Brown } \\
(\%)\end{array}$ & $\begin{array}{l}\text { Melanic } \\
(\%)\end{array}$ & $\begin{array}{l}\text { Gley } \\
(\%)\end{array}$ & $\begin{array}{l}\text { Organic } \\
(\%)\end{array}$ & $\begin{array}{l}\text { Pallic } \\
(\%)\end{array}$ & $\begin{array}{l}\text { Non-soil } \\
(\%)\end{array}$ & $\begin{array}{l}\text { Total } \\
(\%)\end{array}$ & $\begin{array}{l}\text { Total } \\
\text { (ha) }\end{array}$ \\
\hline 1 & 0.9 & 52.9 & 0.34 & 11.4 & 0.04 & 17.8 & 1.25 & 84.6 & 7548 \\
\hline 2 & 0.1 & 9.6 & 0.01 & 1.7 & - & 2.9 & 0.08 & 14.4 & 1285 \\
\hline 3 & 0.1 & 0.5 & - & 0.1 & - & 0.05 & - & 0.7 & 66 \\
\hline 4 & - & 0.3 & - & & - & & - & 0.3 & 26 \\
\hline Total & 1.1 & 63.3 & 0.35 & 13.2 & 0.04 & 20.7 & 1.3 & 100.0 & 8925 \\
\hline
\end{tabular}


Percentage area and area of soil drainage classes for winter-grazed forage crop paddocks for different frequency classes, for high-certainty class only

\begin{tabular}{lcccccccc}
\hline & \multicolumn{1}{c}{ Soil drainage } \\
\cline { 2 - 9 } $\begin{array}{l}\text { Frequency } \\
\text { (years cropped) }\end{array}$ & $\begin{array}{c}\text { Well } \\
(\%)\end{array}$ & $\begin{array}{c}\text { Moderately- } \\
\text { well }(\%)\end{array}$ & $\begin{array}{c}\text { Imperfectly } \\
(\%)\end{array}$ & $\begin{array}{c}\text { Poorly } \\
(\%)\end{array}$ & $\begin{array}{c}\text { Very- } \\
\text { poorly (\%) }\end{array}$ & $\begin{array}{c}\text { Blank } \\
(\%)\end{array}$ & $\begin{array}{c}\text { Total } \\
(\%)\end{array}$ & $\begin{array}{c}\text { Total } \\
(\text { ha) }\end{array}$ \\
\hline 1 & 19.9 & 12.0 & 25.7 & 26.8 & 0.04 & 0.1 & 84.6 & 7548 \\
2 & 2.6 & 1.9 & 5.7 & 4.1 & - & - & 14.4 & 1285 \\
3 & 0.1 & 0.4 & 0.2 & 0.1 & - & - & 0.7 & 66 \\
4 & 0.2 & 0.04 & 0.04 & 0.01 & - & - & 0.3 & 26 \\
\hline Total & 22.8 & 14.4 & 31.6 & 31.1 & 0.04 & 0.1 & 100.0 & 8925 \\
\hline
\end{tabular}

be false negatives due to: the early development stage of the mapping methods; the limitation of having only three image dates in the series; and the imagery (SPOT5) having only four spectral bands. Classification of areas in forage from the 2014 and 2017 image data are considered to be a more accurate representation of the total area in forage. The 2018 result may be a slight under-estimate of the true area as spectral signatures were generated from a region with little fodder beet or swedes (Hawke's Bay) and then applied throughout the country (Belliss et al. 2019). Development of the mapping method has continued since then, with improved results expected in the future.

Smith et al. (2012) showed that annual nitrate losses from leaching increase when winter-grazed forage crops are grown and grazed over successive years on the same area. Their results were for years 2 and 3 for forage crops grazed during each of three consecutive years. Their study was on a shallow Orthic Brown soil reported as free-draining, and there was low rainfall and drainage in year 1. Areas classified as forage with high certainty from the combined 2013/14 and 2017/18 datasets indicate that farmers in the study area planted two consecutive years of winter forage crop in the same paddock $31 \%$ or $21 \%$ of the time, respectively. Thus, the increased annual nitrate losses reported by Smith et al. (2012) could occur in these cases, but losses will depend on individual circumstances. We did not have three consecutive years of winter forage maps, so could not determine the frequency of this occurrence.

Some studies on the environmental effects of wintergrazed forage crops were undertaken on Mottled Fragic Pallic soils, which have restricted permeability (e.g. McDowell et al. 2003a; Drewry \& Paton 2005; Houlbrooke et al. 2009; Monaghan et al. 2017). Fewer studies have been undertaken on soils with good permeability (i.e. some Brown soils) especially in southern New Zealand (e.g. Smith et al. 2012). Note that natural profile soil drainage characteristics are determined from soil morphology for these drainage classes. Soil-order data from S-map are likely to capture broader soil trends due to the scale of mapping, but are unlikely to capture local variability of interest to farmers. Alluvial soils in the Mataura river valley have high spatial variability in soil properties (S Hainsworth pers. comm.), as they are derived from fluvial processes and so have less predictable drainage characteristics than for loess soils on higher river terraces. Artificial drainage, e.g. tile drains, may also affect environmental impacts. McDowell et al. (2003b) reported that Brown soils occupy $48 \%$ of lowland Southland yet little data exist on the drainage characteristics of Brown soils, under winter-grazed forage paddocks. This soil order was the most common in winter-grazed forage paddocks in our study so we suggest that investigations of winter-grazed forage crops on Brown soils are underrepresented in southern New Zealand.

Winter grazing and treading of forage crops often increases greenhouse gases emitted from soil and nitrogen losses to drainage water (van der Weerden et al. 2017; Thomas et al. 2019; Hu et al. 2020), due to wet conditions, low uptake of nutrients in cold conditions, and high stock and urine patch densities (Shepherd et al. 2012). However, lower ruminant methane emissions from brassica and fodder beet (cf. ryegrass and clover) may play a role in offsetting the overall gas emissions (NZAGRC \& PGgRc 2018). In addition, new mitigation practices such as use of subsequent catch-crops for nutrient uptake (Carey et al. 2016; Carey et al. 2017; Malcolm et al. 2020), and strategic grazing (Monaghan et al. 2017) have been developed. Industry best-practice guidelines for farmers have been developed (DairyNZ 2014; Beef + Lamb New Zealand 2017, 2019) from these and other studies. However, we could not find specific recommendations for the number of times a paddock should be re-cropped for winter forage. The spatial extent of strategic grazing and catch-crop practice adoption is not well known, and is not currently captured in satellite-derived winterforage maps. 


\section{Conclusions and recommendations}

We have shown that mapping of winter forage area, particularly when assessed across multiple years, can potentially contribute to the study of a range of environmental questions related to winter forage grazing. Our study was, however, carried out on only a small pilot area, and was limited by the differences in mapping methodologies of the winter-forage source maps we used. We have greater confidence in the certainty of results in the latter years than in earlier years of this study, due to the ongoing improvements in the methodologies behind the source maps.

The 2014 and 2017 winter forage maps cover the whole of Southland so could be used for a whole-region study. However, they are not in consecutive years, and thus the repeat-cropping questions could not be addressed using these data layers. Ideally, in future, more frequent mapping could be carried out using consistent methodology; this would make multi-year studies more powerful and enable regular monitoring. It would also be valuable to investigate whether management practices such as strategic-grazing and catch-cropping are detectable in time-series satellite imagery.

The frequency of repeat cropping of winter-grazed forage crops is a knowledge gap, and the method demonstrated here is one of the few possible ways to fill it. We could not find specific recommendations for the number of times a paddock should be re-cropped for winter forage, so further research is warranted on cumulative effects of winter-forage grazing. In our study, most of the paddocks were used in only one of the four years mapped.

We conclude that experimental studies of wintergrazed forage crops on well-drained soils, such as Brown soils, are under-represented in southern areas because many experimental studies are on Mottled Fragic Pallic soils which have restricted permeability. This lack of information about the well-drained soils is an important knowledge gap. Assessment of greenhouse gas emissions would also benefit from the type of approach used here, where paddock-scale landuse data is geographically aligned with soils data, and the two factors can be studied in combination.

The practical implications of this study include use of the information when designing and developing best management practices and for regional policies. Regular, large-area mapping using consistent methods would make it possible to generate the types of data demonstrated here with greater certainty, frequency, and geographic coverage.

\section{ACKNOWLEDGEMENTS}

We thank Environment Southland and Ministry for the Environment for permission to use some of their earlier results for this paper. We thank John Dymond,
David Pairman, Jan Zoerner, and James Shepherd for assistance with the 2018 data and report, Sharn Hainsworth and Lauren O'Brien, and three anonymous reviewers for comments that improved the manuscript, and Anne Austin for editing. Principal funding was provided by the New Zealand Ministry of Business, Innovation and Employment for the Advanced Remote Sensing Aotearoa programme (contract C09X1709).

\section{SUPPLEMENTARY INFORMATION}

Online Additional File: Maps of winter-forage frequency for high-certainty classes in 2013/2014 and 20132018, and a reference to the 2018 data. https://www. nzgajournal.org.nz/index.php/JoNZG/article/view/425

\section{REFERENCES}

Beef + Lamb New Zealand. 2017. Winter forage crops: management after grazing. Fact sheet 129. https:// beeflambnz.com/knowledge-hub/PDF/winterforage-crops-management-after-grazing

Beef + Lamb New Zealand. 2019. Winter forage crops: management during grazing. Fact sheet 128. https:// beeflambnz.com/knowledge-hub/PDF/winterforage-crops-management-during-grazing.pdf

Belliss SE, Pairman D, Dymond J, Amies A, Zoerner J, Shepherd J, North H, Drewry J. 2019. Identification of high-risk agricultural activities: national mapping of the location, scale and extent of winter forage cropping and intensive grazing on hill country land. Prepared for Ministry for the Environment. [Manaaki Whenua - Landcare Research contract report number: LC3469]. Lincoln: Manaaki Whenua - Landcare Research, 51 p. https://www.mfe. govt.nz/sites/default/files/media/Fresh\%20water/ identification-of-high-risk-agricultural-activities-onhill-country-land.pdf.

Carey PL, Cameron KC, Di HJ, Edwards GR, Chapman DF. 2016. Sowing a winter catch crop can reduce nitrate leaching losses from winter-applied urine under simulated forage grazing: a lysimeter study. Soil Use and Management 32: 329-337. https://doi. org/10.1111/sum. 12276

Carey PL, Cameron KC, Di HJ, Edwards GR. 2017. Comparison of nitrate leaching from oats and Italian ryegrass catch crops following simulated winter forage grazing: a field lysimeter study. New Zealand Journal of Agricultural Research 60: 298-318. https://doi.org/10.1080/00288233.2017.1336103

Carrick S, Palmer D, Webb T, Scott J, Lilburne L. 2013. Stony soils are a major challenge for nutrient management under irrigation development. Presented at: Accurate and efficient use of nutrients on farms. Palmerston North. Pp. 1-8. https://www. massey.ac.nz/ flrc/workshops/13/Manuscripts/ Paper_Carrick_1_2013.pdf 
DairyNZ. 2014. Reducing surface runoff from grazed winter forage crop paddocks by strategic grazing management.

Drewry JJ, Paton RJ. 2005. Soil physical quality under cattle grazing of a winter-fed brassica crop. Australian Journal of Soil Research 43: 525-531. https://doi.org/10.1071/SR04122

Hewitt A. 2010. New Zealand soil classification. 3rd ed. Lincoln, New Zealand: Landcare Research, 136 p.

Houlbrooke DJ, Paton RJ, Morton JD, Littlejohn RP. 2009. Soil quality and plant yield response under dryland and irrigated winter forage crops by sheep or cattle. Australian Journal of Soil Research 47: 470477. https://doi.org/10.1071/SR08228

$\mathrm{Hu}$ W, Beare M, Tregurtha C, Gillespie R, Lehto $\mathrm{K}$, Tregurtha R, Gosden P, Glasson S, Dellow S, George M, Tabley F, Qiu W, Baird D. 2020. Effects of tillage, compaction and nitrogen inputs on crop production and nitrogen losses following simulated forage crop grazing. Agriculture, Ecosystems \& Environment 289: 106733. https://doi.org/10.1016/j. agee.2019.106733

Judson HG, Dalley DE, Edwards GR, Stevens DR, Gibbs SJ. 2010. Improving winter feeding outcomes in South Island dairy herds. Proceedings of the $4^{\text {th }}$ Australasian Dairy Science Symposium 2010. Pp. 137-143.

Lilburne LR, Hewitt AE, Webb TW. 2012. Soil and informatics science combine to develop S-map: A new generation soil information system for New Zealand. Geoderma 170: 232-238. https://doi. org/10.1016/j.geoderma.2011.11.012

Malcolm BJ, de Ruiter JM, Dalley DE, Carrick S, Waugh D, Arnold NP, Dellow SJ, Beare MH, Johnstone PR, Wohlers M, Brown H, Welten B, Horrocks AJ. 2020. Catch crops and feeding strategy can reduce the risk of nitrogen leaching in late lactation fodder beet systems. New Zealand Journal of Agricultural Research 63: 44-64. https://doi.org/10.1080/002882 33.2019 .1704422

McDowell RW, Drewry JJ, Paton RJ, Carey PL, Monaghan RM, Condron LM. 2003a. Influence of soil treading on sediment and phosphorus losses in overland flow. Australian Journal of Soil Research 41: 949-961. https://doi.org/10.1071/SR02118

McDowell RW, Monaghan RM, Morton J. 2003b. Soil phosphorus concentrations to minimise potential $\mathrm{P}$ loss to surface waters in Southland. New Zealand Journal of Agricultural Research 46: 239-253. https://doi.org/10.1080/00288233.2003.9513550

Milne JDG, Clayden B, Singleton PL, Wilson AD. 1995. Soil description handbook. Revised ed. Lincoln, New Zealand: Manaaki Whenua Press, 157 p.
Monaghan R, Laurenson S, Dalley D, Orchiston T. 2017. Grazing strategies for reducing contaminant losses to water from forage crop fields grazed by cattle during winter. New Zealand Journal of Agricultural Research 60: 333-348. https://doi.org/1 0.1080/00288233.2017.1345763

North H, Belliss S. 2015. Winter livestock forage map Southland Region 2014. [Landcare Research Contract Report LC2143 for Environment Southland]. Lincoln: Landcare Research, 31 p. https://www.es.govt. nz/repository/libraries/id:26gi9ayo517q9stt81sd/ hierarchy/environment/land-and-soil/soil-reports/ documents/winter livestock forage mapsouthland region 2014 3mar15.pdf

North HC, Pairman D, Belliss SE. 2019. Boundary delineation of agricultural fields in multitemporal satellite imagery. IEEE Journal of Selected Topics in Applied Earth Observations and Remote Sensing 12: 237-251. https://doi.org/10.1109/ JSTARS.2018.2884513

NZAGRC \& PGgRc. 2018. Reducing New Zealand's agricultural greenhouse gases: low greenhouse gas emitting feeds. Palmerston North: New Zealand Agricultural Greenhouse Gas Research Centre and Pastoral Greenhouse Gas Research Consortium, 7 p. https://www.pggrc.co.nz/files/1554327577875.pdf

Pearson L, Couldrey M, Rodway E. 2016. Spatial analysis of winter forage cropping in Southland and the implications for water quality management. Technical Report. [SRC Publication No 201613]. Invercargill: Environment Southland, $57 \mathrm{p}$. https://www.es.govt.nz/repository/libraries/ id:26gi9ayo517q9stt81sd/hierarchy/environment/ land-and-soil/soil-reports/documents/Technical $\% 20$ Report $\% 20-\% 20$ Spatial\%20analysis $\% 20$ of $\% 20$ winter $\% 20$ forage $\% 20$ cropping $\% 20$ in $\% 20$ Southland\%20\%28PDF\%29.pdf

Shepherd M, Stafford A, Smeaton D. 2012. The use of a nitrification inhibitor (DCn) to reduce nitrate leaching under a winter-grazed forage crop in the Central Plateau. Proceedings of the New Zealand Grassland Association 74: 103-108. https://doi. org/10.33584/jnzg.2012.74.2891

Smith LC, Orchiston T, Monaghan RM. 2012. The effectiveness of the nitrification inhibitor dicyandiamide (DCD) for mitigating nitrogen leaching losses from a winter grazed forage crop on a free draining soil in northern Southland. Proceedings of the New Zealand Grassland Association 74: 3944. https://doi.org/10.33584/jnzg.2012.74.2882

Thomas SM, Fraser PM, Hu W, Clough TJ, van der Klei G, Wilson S, Tregurtha R, Baird D. 2019. Tillage, compaction and wetting effects on $\mathrm{NO}_{3}, \mathrm{~N}_{2} \mathrm{O}$ and $\mathrm{N}_{2}$ losses. Soil Research 57: 670-688. https://doi. org/10.1071/SR18261 
van der Weerden TJ, Styles TM, Rutherford AJ, de Klein CAM, Dynes R. 2017. Nitrous oxide emissions from cattle urine deposited onto soil supporting a winter forage kale crop. New Zealand Journal of Agricultural Research 60: 119-130. https://doi.org/1 $0.1080 / 00288233.2016 .1273838$ 